MATEC Web of Conferences 25, 04009 (2015)

DOI: $10.1051 /$ matec conf/ 20152504009

(C) Owned by the authors, published by EDP Sciences, 2015

\title{
Straight Joint Shear Performance Test of Urban Sludge Sintered Shale Bricks
}

\author{
Zhi Li \\ College of Civil and Architectural Engineering, Guangxi University of Science and Technology, Liuzhou, \\ Guangxi, China \\ Bingzhang Huang \\ University of Portsmouth, United Kingdom \\ Bangbiao Huang, Jizhen Zhu, Jun Lai, Tianquan Liao \& Bei Zhang \\ College of Civil and Architectural Engineering, Guangxi University of Science and Technology, Liuzhou, \\ Guangxi, China
}

\begin{abstract}
In the actual engineering design, it is too conservative for the calculation results for the urban sludge sintered shale brick to use the shear strength formula in the Design Specifications of Masonry Structure. To more effectively calculate this formula, this paper researches the straight joint shear performance test of urban sludge sintered solid shale bricks and porous brick masonry, and analyzes the failure mode of two kinds of brick masonry, and reaches the proposed formula of the straight joint shear strength. Then, this paper compares the proposed formula with the corresponding formulas in the specification, and reaches a high safety stock of the formula in the specification, and needs to correct the coefficient of material properties in the formula in the specification.
\end{abstract}

Keywords: urban sludge; shear strength; safety stock; coefficient of material properties

\section{INTRODUCTION}

From 2013 to 2015, there is also a need to dispose 3.78 million tons of urban sludge, namely, 10,400 tons of sludge per day. How to harmlessly dispose the urban sludge has become one of difficult and key problems in the urban development nowadays. The use of urban sludge sintered shale brick is one of important means to harmlessly dispose the sludge. In the process of sintering sludge shale brick, the silicate in the urban sludge melts and wraps heavy metal ${ }^{[1-2]}$, and the combustion of organic matter forms a lot of tiny holes inside the brick. Therefore, the urban sludge sintered shale brick has the following advantages, such as light weight, sound insulation, heat preservation and so on. The research group carries out a large number of researches for the shale brick and concrete block as the test reference, so as to lay a solid foundation for the promotion of the urban sludge sintered shale brick.

\section{TEST OVERVIEW}

\subsection{Brick types in the test}

The urban sludge sintered solid shale brick and the porous brick masonry used in the test are selected from Gulinger Brick Factory in Liuzhou City. The porous brick is a standard KP1 type with the size of
$240 \mathrm{~mm} \times 115 \mathrm{~mm} \times 90 \mathrm{~mm}$, hole ratio of $28 \%$, and hole pattern of rectangular hole. The size of the solid brick is $240 \mathrm{~mm} \times 115 \mathrm{~mm} \times 53 \mathrm{~mm}$.

\subsection{Test of material properties}

In the brick factory, we usually select bricks just by making a simple judgment on the basis of the color and weight of the brick rather than exact division of concrete strength grade of the bricks. Obviously, such a subjective judgment will result in errors. In the same batch of bricks, the strength of brick is also very different due to the difference in sintering temperature and holding time.

This test adopts the resiliometer rating method to select bricks. According to the requirements of resiliometer rating method of the grade of sintered common brick and sintered brick (JC\T769-1999), HT75-type resiliometer is used to test the quality and strength of single brick. The resiliometer rating method is used to select 400 pieces of the urban sludge sintered solid shale bricks and porous bricks at the same grade.

\subsubsection{Compressive strength of single brick}

To select 10 pieces of the urban sludge sintered solid shale bricks and porous bricks with smooth surface and without obvious cracks or defects from 800 pieces of bricks that are selected by the resiliometer, the 
MATEC Web of Conferences

Table 1. Measured values of the compressive strength of single brick of the urban sludge sintered solid shale bricks

\begin{tabular}{llllll}
\hline Specimen No. & $\begin{array}{l}\text { Specimen size } \\
\text { Length }(\mathrm{mm})\end{array}$ & Width(mm) & Pressure value $(\mathrm{N})$ & $\begin{array}{l}\text { Compressive strength } \\
(\mathrm{Mpa})\end{array}$ & $\begin{array}{l}\text { Mean compressive strength } \\
(\mathrm{Mpa})\end{array}$ \\
\hline 1 & 108 & 98 & 177282 & 16.75 & \\
2 & 112 & 100 & 181552 & 16.21 & 15.29 \\
3 & 110 & 105 & 170709 & 14.78 & \\
4 & 107 & 104 & 168700 & 15.16 & \\
5 & 114 & 110 & 170293 & 13.58 & \\
\hline
\end{tabular}

Table 2. Measured values of the compressive strength of single brick of porous brick in the urban sludge sintered shale bricks

\begin{tabular}{|c|c|c|c|c|c|}
\hline \multirow{2}{*}{ Specimen No. } & \multicolumn{2}{|l|}{ Specimen size } & \multirow{2}{*}{ Pressure value $(\mathrm{N})$} & \multirow{2}{*}{$\begin{array}{l}\text { Compressive strength } \\
(\mathrm{Mpa})\end{array}$} & \multirow{2}{*}{$\begin{array}{l}\text { Mean compressive strength } \\
\text { (Mpa) }\end{array}$} \\
\hline & Length(mm) & Width(mm) & & & \\
\hline 1 & 240 & 114 & 294940 & 10.78 & \\
\hline 2 & 239 & 115 & 308656 & 11.23 & \\
\hline 3 & 240 & 113 & 277980 & 10.25 & 10.55 \\
\hline 4 & 241 & 114 & 277762 & 10.11 & \\
\hline 5 & 238 & 115 & 284921 & 10.41 & \\
\hline
\end{tabular}

Table 3. Measured values of straight joint shear strength of mortar in the urban sludge sintered shale brick

\begin{tabular}{lllll}
\hline Specimen label & M2.5(MPa) & M5(MPa) & M7.5(MPa) & M10(MPa) \\
\hline 1 & 2.73 & 5.14 & 7.45 & 9.35 \\
2 & 3.15 & 6.25 & 7.21 & 9.27 \\
3 & 2.49 & 5.38 & 7.78 & 8.96 \\
4 & 2.36 & 5.33 & 7.62 & 8.88 \\
5 & 3.44 & 5.49 & 6.87 & 9.13 \\
6 & 2.82 & 6.66 & 7.86 & 9.72 \\
Mean value & 2.83 & 5.71 & 7.47 & 9.22 \\
\hline
\end{tabular}

compression test and calculation of single brick is carried out according to the test method of wall bricks (GB/T2542-2003). The data are also recorded as shown in Table 1 and Table 2.

As can be seen from Table 1 and Table 2, the compressive strength of the solid brick is higher than that of the porous brick. This is because the porous bricks are prone to be crushed in the place of holes and around the bricks, but the solid bricks are dense inside. Due to the impact of holes, the internal porous brick is loose, so that the compressive strength of single brick of the porous bricks is smaller than that of the single brick of the solid bricks.

\subsubsection{Test of mortar strength}

The cement used in the test is ordinary Portland cement manufactured by the cement factory in Liuzhou City. The mortar is prepared by a certain percentage of the cement, lime putty and rive sand. The mortar strength has a certain impact on the shear strength of the brick, so the test of mortar strength is carried out, and the test data are shown in Table 3.

\subsection{Production of shear specimens}

This test uses two different types of bricks. One is solid bricks, and the other is KP1-type porous bricks with rectangular holes. Three layers of bricks are built together, and each layer is constructed with three pieces of bricks. Its dimensions are respectively $179 \mathrm{~mm} \times 240 \mathrm{~mm} \times 365 \mathrm{~mm}$ and $290 \mathrm{~mm} \times 240 \mathrm{~mm} \times$ $360 \mathrm{~mm}$ (nine-brick masonry specimens). This test uses four different strength grades of mortar, which are respectively M2.5, M5, M7.5 and M10. They are respectively constructed with the urban sludge sintered solid shale brick and the urban sludge sintered porous shale brick according to the standard of basic mechanical property test method (GBT50129-2011). According to the strength grade of mortar, each type of brick produces 9 groups of specimens with a total of 72 specimens. 
EMME 2015

\subsection{Test procedures}

The straight joint shear test of the urban sludge sintered shale brick adopts the screen-displayed electro-hydraulic servo universal testing machine. Before the test, there is a need to find the center position of the testing machine with a drop hammer, and make a mark; in the test, take a large area of rigid cushion block to place below the testing machine, and pave a layer of thin sand on the rigid cushion block to ensure the smoothness of the specimen, and then place two pieces of small rigid cushion block on the large rigid cushion block according to the position of masonry mortar joint, so as to ensure that their distance is greater than the width of the bricks. After adjustment of the device, there is a need to use computer to control the loading rate, carefully observe the failure mode of the specimen. The control specimens are destroyed within 3 minutes, and the failure load is recorded.

Table 4. Measured values of shear strength of solid brick in the urban sludge sintered shale brick

\begin{tabular}{|c|c|c|c|c|c|c|c|c|}
\hline \multirow[b]{2}{*}{$\begin{array}{l}\text { Mortar strength } f_{2} \\
\text { No. }\end{array}$} & \multicolumn{2}{|c|}{$2.83(\mathrm{MPa})$} & \multicolumn{2}{|c|}{$5.71(\mathrm{MPa})$} & \multicolumn{2}{|c|}{ 7.47(MPa) } & \multicolumn{2}{|c|}{$9.22(\mathrm{MPa})$} \\
\hline & $\begin{array}{l}\text { Failure } \\
\text { load } N_{v} \\
(\mathrm{~N})\end{array}$ & $\begin{array}{l}\text { Shear } \\
\text { strength } f_{v} \\
\left(\mathrm{~N} / \mathrm{mm}^{2}\right)\end{array}$ & $\begin{array}{l}\text { Failure } \\
\operatorname{load} N_{v} \\
(\mathrm{~N})\end{array}$ & $\begin{array}{l}\text { Shear } \\
\text { strength } f_{v} \\
\left(\mathrm{~N} / \mathrm{mm}^{2}\right)\end{array}$ & $\begin{array}{l}\text { Failure } \\
\text { load } N_{v} \\
\text { (N) }\end{array}$ & $\begin{array}{l}\text { Shear } \\
\text { strength } f_{v} \\
\left(\mathrm{~N} / \mathrm{mm}^{2}\right)\end{array}$ & $\begin{array}{l}\text { Failure } \\
\text { load } N_{v} \\
\text { (N) }\end{array}$ & $\begin{array}{l}\text { Shear } \\
\text { strength } f_{v} \\
\left(\mathrm{~N} / \mathrm{mm}^{2}\right)\end{array}$ \\
\hline 1 & 18216 & 0.33 & 26496 & 0.48 & 28704 & 0.52 & 27048 & 0.49 \\
\hline 2 & 11592 & 0.21 & 23184 & 0.42 & 30912 & 0.56 & 29808 & 0.54 \\
\hline 3 & 17112 & 0.31 & 21528 & 0.39 & 33672 & 0.61 & 25392 & 0.46 \\
\hline 4 & 16008 & 0.29 & 28152 & 0.51 & 28152 & 0.51 & 24840 & 0.45 \\
\hline 5 & 15456 & 0.28 & 24840 & 0.45 & 26496 & 0.48 & 28704 & 0.52 \\
\hline 6 & 17664 & 0.32 & 18216 & 0.33 & 30360 & 0.55 & 26496 & 0.48 \\
\hline 7 & 16008 & 0.29 & 23736 & 0.43 & 28152 & 0.51 & 30360 & 0.55 \\
\hline 8 & 13800 & 0.25 & 24840 & 0.45 & 30360 & 0.55 & 28704 & 0.52 \\
\hline 9 & 17664 & 0.32 & 22632 & 0.41 & 35328 & 0.64 & 29256 & 0.53 \\
\hline $\begin{array}{l}\text { Mean value of shear } \\
\text { strength test } \\
\mathrm{f}_{\mathrm{v}, \mathrm{m}}\left(\mathrm{N} / \mathrm{mm}^{2}\right)\end{array}$ & & 0.29 & & 0.43 & & 0.55 & & 0.50 \\
\hline
\end{tabular}

Table 5. Measured values of shear strength of porous brick in the urban sludge sintered shale brick

\begin{tabular}{|c|c|c|c|c|c|c|c|c|}
\hline \multirow[b]{2}{*}{$\begin{array}{l}\text { Mortar strength } f_{2} \\
\text { No. }\end{array}$} & \multicolumn{2}{|c|}{$2.83(\mathrm{MPa})$} & \multicolumn{2}{|c|}{$5.71(\mathrm{MPa})$} & \multicolumn{2}{|c|}{ 7.47(MPa) } & \multicolumn{2}{|c|}{$9.22(\mathrm{MPa})$} \\
\hline & $\begin{array}{l}\text { Failure } \\
\text { load } N_{v} \\
\text { (N) }\end{array}$ & $\begin{array}{l}\text { Shear } \\
\text { strength } f_{v} \\
\left(\mathrm{~N} / \mathrm{mm}^{2}\right)\end{array}$ & $\begin{array}{l}\text { Failure } \\
\text { load } N_{v} \\
\text { (N) }\end{array}$ & $\begin{array}{l}\text { Shear } \\
\text { strength } f_{v} \\
\left(\mathrm{~N} / \mathrm{mm}^{2}\right)\end{array}$ & $\begin{array}{l}\text { Failure } \\
\text { load } N_{v} \\
(\mathrm{~N})\end{array}$ & $\begin{array}{l}\text { Shear } \\
\text { strength } f_{v} \\
\left(\mathrm{~N} / \mathrm{mm}^{2}\right)\end{array}$ & $\begin{array}{l}\text { Failure } \\
\operatorname{load} N_{v} \\
(\mathrm{~N})\end{array}$ & $\begin{array}{l}\text { Shear } \\
\text { strength } f_{v} \\
\left(\mathrm{~N} / \mathrm{mm}^{2}\right)\end{array}$ \\
\hline 1 & 17664 & 0.32 & 23736 & 0.43 & 23736 & 0.43 & 34776 & 0.63 \\
\hline 2 & 16008 & 0.29 & 28152 & 0.51 & 30360 & 0.55 & 32568 & 0.59 \\
\hline 3 & 17112 & 0.31 & 26496 & 0.48 & 27048 & 0.49 & 32016 & 0.58 \\
\hline 4 & 17664 & 0.32 & 19872 & 0.36 & 22080 & 0.40 & 30360 & 0.55 \\
\hline 5 & 17112 & 0.31 & 22632 & 0.41 & 28152 & 0.51 & 36432 & 0.66 \\
\hline 6 & 19320 & 0.35 & 25944 & 0.47 & 25944 & 0.47 & 28704 & 0.52 \\
\hline 7 & 17112 & 0.31 & 23184 & 0.42 & 28152 & 0.51 & 33672 & 0.61 \\
\hline 8 & 22632 & 0.41 & 25944 & 0.47 & 27048 & 0.49 & 29808 & 0.54 \\
\hline 9 & 18768 & 0.34 & 22632 & 0.41 & 26496 & 0.48 & 35328 & 0.64 \\
\hline $\begin{array}{l}\text { Mean value of shear } \\
\text { strength test } \\
\mathrm{f}_{\mathrm{v}, \mathrm{m}}\left(\mathrm{N} / \mathrm{mm}^{2}\right)\end{array}$ & & 0.33 & & 0.44 & & 0.48 & & 0.59 \\
\hline
\end{tabular}




\section{MATEC Web of Conferences}

3 TEST RESULTS AND THEORETICAL ANALYSIS

\subsection{Failure phenomena of specimens}

In the straight joint shear test of the urban sludge sintered solid shale brick and porous brick, the failure of specimens belongs to brittle failure. The specimens are suddenly destroyed at the ultimate failure load without any warning, and the masonry loses its bearing capacity. The test shows that the porous bricks and solid bricks have three kinds of masonry failure modes, namely, the double shear failure mode, the single shear failure mode and the brick failure mode.

The test is carried out based on the standard of basic mechanical property test method (GBT50129-2011). The shear test data of the solid brick masonry and porous brick masonry are shown in Table 4 and Table 5 . The formula of the shear strength of the cross section of straight joint is:

$f_{v, m}=\frac{N_{v}}{2 A}$

Where: $f_{v, m}$ - the shear strength of the cross section of straight joint (Unit: $\mathrm{N} / \mathrm{mm}^{2}$ );

$N_{v}$ - the shear failure load value of specimens (Unit: $\mathrm{N}$ );

A-the shear surface area of specimens (Unit: $\mathrm{mm}^{2}$ ).

As can be seen from Table 4 and Table 5, the mean value of shear strength test of the porous brick is greater than that of the solid brick. As can be seen from Figures 4, 6 and 8, there are three kinds of ma- sonry failure modes, and the mortar pin keys have a very high fill rate. In the masonry shear test, it indicates that the mortar pin key plays an important role in bearing the shearing force of the masonry if the mortar pin key is cut by the shearing force.

In order to facilitate comparison, the regression analysis is given to the data. According to the existing design specification of the masonry structure (GB50003-2011 [s]):

$$
f_{v, m}=k \sqrt{f_{2}}
$$

\section{Where:}

$f_{v, m}$ - the shear strength of the cross section of straight joint of the specimen (Unit: N/mm²);

$\mathrm{k}$ - the coefficient of material properties with the specification of 0.125 ;

$f_{2}$ - the mean value of compressive strength of mortar (Unit; $\mathrm{N} / \mathrm{mm}^{2}$ ).

The least square method is used to process the test data in Table 4, obtaining the data linear regression of the mean value of shear strength:

$$
f_{v, m}=0.1800 \sqrt{f_{2}}
$$

The least square method is used to process the test data in Table 5, obtaining the data linear regression of the mean value of shear strength:

$f_{v, m}=0.1869 \sqrt{f_{2}}$

The linear regression plot is shown in Figure 1.

As can be seen from Figure 1 and Figure 2, it shows

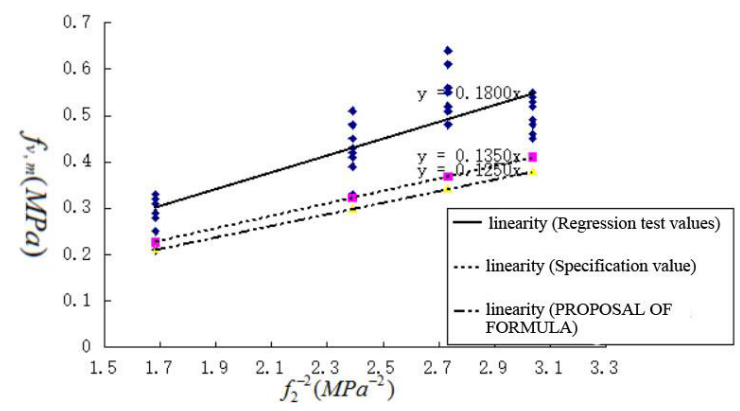

Figure 1. Shear measured values and regression values of the urban sludge sintered solid shale brick

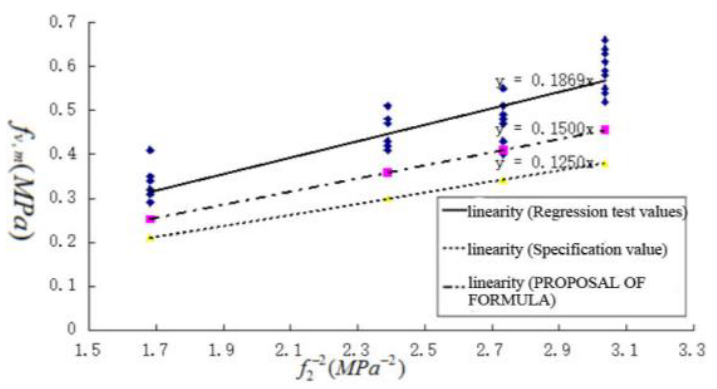

Figure 2. Distribution diagram of measured values and regression values of the urban sludge sintered porous shale brick 
that the test values in Table 4 and Table 5 are much higher than that of the requirements in the specifications. That is, the minimum value is much higher than that of the requirements in the specifications, so the test values above the fitting straight line are safe. As can be seen from the diagram, a part of test values are still below the fitting straight line. It may be unsafe. Therefore, it is necessary to adjust the coefficient of material properties $(K)$ in the formulas (3) and (4), so as to make the adjusted formula become the lower boundary line of the test point.

With the spreadsheet, after adjusting the value of $\mathrm{k}$ in the formula (3) as $0.135,\left(f_{v, m}-f_{v, \text { min }}\right) / f_{v, m}$ can be controlled within $5 \%{ }^{[13]}$ :

$$
f_{v, m}=0.135 \sqrt{f_{2}}
$$

Table 6. Comparison of calculated value in the formula (5) and minimum value in the test (Mpa)

\begin{tabular}{lcccc}
\hline Mortar strength $f_{2}$ & 2.83 & 5.71 & 7.47 & 9.22 \\
\hline $\begin{array}{l}\text { Calculated value in the } \\
\text { formula (6) } f_{v, m}\end{array}$ & 0.22 & 0.32 & 0.37 & 0.41 \\
$\begin{array}{l}\text { Minimum value in each } \\
\text { set of test } f_{v, \text { min }}\end{array}$ & 0.21 & 0.33 & 0.48 & 0.45 \\
$\left(f_{v, m}-f_{v, \text { min }}\right) / f_{v, m}$ & 0.045 & -0.031 & -0.297 & --0.097 \\
\hline
\end{tabular}

Then, make a trial adjustment of the coefficient of material properties $(\mathrm{k})$ in the formula (4). After adjusting the value of $\mathrm{k}$ as $0.150,\left(f_{v, m}-f_{v, \min }\right) / f_{v, m}$ can be controlled within $5 \%$ :

$$
f_{v, m}=0.150 \sqrt{f_{2}}
$$

Table 7. Comparison of calculated value in the formula (6) and minimum value in the test (Mpa)

\begin{tabular}{lllll}
\hline Mortar strength $f_{2}$ & 2.83 & 5.71 & 7.47 & 9.22 \\
\hline $\begin{array}{l}\text { Calculated value in the } \\
\text { formula (7) } f_{v, m}\end{array}$ & 0.25 & 0.36 & 0.41 & 0.46 \\
$\begin{array}{l}\text { Minimum value in each } \\
\text { set of test } f_{v, \text { min }}\end{array}$ & 0.29 & 0.41 & 0.40 & 0.52 \\
$\left(f_{v, m}-f_{v, \text { min }}\right) / f_{v, m}$ & -0.160 & -0.139 & 0.024 & -0.130
\end{tabular}

\section{CONCLUSION}

(1) In the straight joint shear test of the urban sludge shale bricks, there are brick failure phenomena in the sold bricks and porous bricks. It is because the brick surface of the urban sludge shale bricks is rough, with a better bonding with mortar. The strength of the urban sludge shale brick is lower than that of the ordinary shale brick, so the bonding strength of the brick and mortar is greater than the brick strength, eventu- ally resulting in brick failure. The brick surface of the urban sludge porous shale bricks is rough and has the effect of pin key, resulting in brick failure phenomena in the porous bricks.

(2) The test value in this test is higher than the code value, so it is recommended that the formula of the straight joint shear strength of the urban sludge sintered solid shale bricks is $f_{v, m}=0.135 \sqrt{f_{2}}$, while the formula of the straight joint shear strength of the urban sludge sintered porous shale bricks is $f_{v, m}=0.150 \sqrt{f_{2}}$.

\section{REFERENCES}

[1] Ren Bozhi, Long Tengrui, \& Chen Qiunan. 2003. Experimental study on utilization of the urban sludge in the process of sintering brick with fly-ash and clay. Journal of Environmental Science, 23 (3): 414-416

[2] Li Shuzhan, Shi Zhou, \& Xie Min. 2007. Production and performance of tiles made from sludge of sewage treatment plant. Journal of the Chinese Ceramic Society, 35 (2): 251-254

[3] Huang Bangbiao, Li Xiqiang, \& Zhu Jizhen, et al. 2012. Impact of temperature on the basic properties of sludge shale brick. Journal of Guangxi University of Technology, 23 (4): 8-11

[4] Huang Bangbiao, Jing Jiahua, \& Huang Zhong, et al. 2011. Impact of temperature on the cracks of light shale-sintered brick. New Building Materials, 38 (3) $37-40$

[5] Huang Bangbiao, Lai Jun, \& Zhu Jizhen, et al. 2015. Performance research on sintering shale bricks manufactured from rice husks. Construction Technology, 4 (4): 116-119

[6] Wu Yuanchang, Zhu Jizhen, \& Huang Bangbiao, et al. 2014. Experimental research on axial compression of sludge sintered porous shale brick masonry. Journal of Guangxi University: Natural Science, 39 (1): 32-37

[7] Hu Shang, Huang Bangbiao, \& Zhu Jizhen, et al. 2011. Experimental study on shear property of masonry mode of concrete multi-row hole bricks. New Building Materials, 28 (3): 28-30

[8] Huang Bangbiao, Lai Jun, \& Zhu Jizhen. 2015. Research on compressive strength and elastic modulus of burnt shale brick masonry with rectangular hole. Journal of Guangxi University: Natural Science, 40 (1): 43-49

[9] Huang Bangbiao, Wang Tao, \& Zhang Xianghua. 2013 Comparison of the composite shear performance with square hole bricks masonry structure and round hole bricks masonry structure. Sichuan Building Materials, 39 (2): 7-11

[10]Huang Bangbiao, Zhang Xianghua, \& Zhu Jizhen, et al. 2012. Impact of sludge proportion on compressive strength of sintered shale bricks. Sichuan Building Materials, 38 (5): 3-4

[11]Huang Bangbiao, Liang Lixin, \& Zhu Jizhen, et al. 2005. Analysis of mechanical properties of small-sized porous concrete bricks. Journal of Guangxi University of Technology, 6 (2): 23-29 


\section{MATEC Web of Conferences}

[12]Huang Bangbiao, Du Yundan, \& Hu Shang, et al. 2011. Experimental study on bending tensile strength of the masonry made of porous concrete bricks. Journal of Guangxi University: Natural Science, 36 (4): 694-698.
[13]Qin Shihong, Hu Jue, \& Luo Wankang, et al. 2005. Experimental study on shear strength of the masonry made of porous bricks of sintered shale gangue. Building Structure, 35 (9): 11-14. 